\title{
Metal-Organic Frameworks (MOFs)-Based Nanomaterials for Drug Delivery
}

\author{
Mohammad Reza Saeb ${ }^{1}$, Navid Rabiee ${ }^{2, *(\mathbb{D})}$, Masoud Mozafari ${ }^{3}$ and Ebrahim Mostafavi $^{4,5, *(\mathbb{D})}$ \\ 1 Université de Lorraine, CentraleSupélec, LMOPS, F-57000 Metz, France; mrsaeb2008@gmail.com \\ 2 Department of Chemistry, Sharif University of Technology, Tehran 11155-3516, Iran \\ 3 Department of Tissue Engineering \& Regenerative Medicine, Faculty of Advanced Technologies in Medicine, \\ Iran University of Medical Sciences, Tehran 14665-354, Iran; m.mozafari@utoronto.ca \\ 4 Stanford Cardiovascular Institute, Stanford University, Stanford, CA 94305, USA \\ 5 Department of Medicine, Stanford University School of Medicine, Stanford, CA 94305, USA \\ * Correspondence: nrabiee94@gmail.com (N.R.); ebimsv@stanford.edu (E.M.)
}

Citation: Saeb, M.R.; Rabiee, N.;

Mozafari, M.; Mostafavi, E.

Metal-Organic Frameworks

(MOFs)-Based Nanomaterials for Drug Delivery. Materials 2021, 14

3652. https://doi.org/10.3390/

ma14133652

Academic Editor: Catherine

P. Raptopoulou

Received: 1 June 2021

Accepted: 26 June 2021

Published: 30 June 2021

Publisher's Note: MDPI stays neutral with regard to jurisdictional claims in published maps and institutional affiliations.

Copyright: (c) 2021 by the authors. Licensee MDPI, Basel, Switzerland. This article is an open access article distributed under the terms and conditions of the Creative Commons Attribution (CC BY) license (https:// creativecommons.org/licenses/by/ $4.0 /)$.

\begin{abstract}
The composition and topology of metal-organic frameworks (MOFs) are exceptionally tailorable; moreover, they are extremely porous and represent an excellent Brunauer-Emmett-Teller (BET) surface area $\left(\approx 3000-6000 \mathrm{~m}^{2} \cdot \mathrm{g}^{-1}\right)$. Nanoscale MOFs (NMOFs), as cargo nanocarriers, have increasingly attracted the attention of scientists and biotechnologists during the past decade, in parallel with the evolution in the use of porous nanomaterials in biomedicine. Compared to other nanoparticle-based delivery systems, such as porous nanosilica, nanomicelles, and dendrimerencapsulated nanoparticles, NMOFs are more flexible, have a higher biodegradability potential, and can be more easily functionalized to meet the required level of host-guest interactions, while preserving a larger and fully adjustable pore window in most cases. Due to these unique properties, NMOFs have the potential to carry anticancer cargos. In contrast to almost all porous materials, MOFs can be synthesized in diverse morphologies, including spherical, ellipsoidal, cubic, hexagonal, and octahedral, which facilitates the acceptance of various drugs and genes.
\end{abstract}

Keywords: metal-organic frameworks; drug delivery; nanomedicine; biomedicine

\section{Strategies for Encapsulation of Cargo into MOFs}

Metal-organic frameworks (MOFs), which are known to be extremely porous crystalline hybrid compounds (possessing a Brunauer-Emmett-Teller (BET) surface area in the range of $\left.\approx 3000-6000 \mathrm{~m}^{2} \cdot \mathrm{g}^{-1}[1]\right)$, are the result of a chemical alliance between an organic unit (i.e., mono-, di-, tri-, or tetravalent ligands, also known as struts or linkers) and an inorganic cluster/ion (i.e., transition or lanthanide metals). One of the advantages of MOFs is their versatility, meaning that their composition and topology are exceptionally tunable; moreover, they are extremely porous and represent an excellent BET surface area. A variety of methods, such as hydrothermal or solvothermal, mechanochemical, spray-drying, ultrasonic/microwave, electrochemical, and diffusion synthesis, have been employed in the development of a wide variety of MOFs that possess the potential for myriad purposes, including energy storage, catalysis, sensor, nonlinear optics, protection of metals against corrosion, semiconductors, solar conversion of fuels, and biomedical applications. In particular, during the past decade, nanoscale MOFs (NMOFs), as cargo nanocarriers, have played an essential role in medicine and biomedical engineering. Compared to other nanoparticle-based delivery systems (such as porous nanosilica, nanomicelles, and dendrimer-encapsulated nanoparticles), NMOFs are more flexible, provide better biodegradability, can be more easily functionalized to meet the required level of host-guest interactions, and offer a wider range of pore size. As a result, they are better candidates to carry anticancer cargos. In contrast to almost all porous materials, such as nanosilica [2,3], MOFs can be synthesized in wider range of diverse morphologies with a 
controlled microstructure, including spherical, ellipsoidal, cubic, hexagonal, and octahedral, which facilitates the acceptance of various drugs and genes. Moreover, fluorescence agents and organic dyes can be encased in MOFs for imaging, photothermal therapy (PTT), and photodynamic therapy (PDT) [4].

The present perspective discusses different properties of MOFs, such as their physical, chemical, and biomedical aspects, in drug delivery systems (DDS). Scheme 1 provides a short overview of the applications of MOFs in drug delivery. Stock and Biswas comprehensively reviewed the effect of the synthesis route on the topology and morphology of MOFs [5]. For instance, microwave-assisted methods mainly result in nanoscale particles of MOFs. Nevertheless, the correct choice of metal determines the efficiency of drug delivery. In addition, for efficient drug delivery, it is essential to functionalize NMOFs (e.g., with $-\mathrm{NH}_{2}$ ). The presence of unreacted linkers in the framework is inevitable in as-synthesized NMOFs. Under such circumstances, the pore dimension significantly depends on the flexibility of the framework. For example, in the case of $X$ - Matériaux de l'Institut Lavoisier (MIL)-53 ( $\mathrm{X}=\mathrm{Fe}, \mathrm{Al}, \mathrm{Cr}$ ), there is a large pore size window by exchange of metals, such that variance in the unit cell volume of up to $60 \%$ is observed with no framework topology change. The most widely used MOFs for drug delivery are Fe metal-based MOFs with bio-organic linkers (MILs; 53, 88, 100, and 101) having a pore size in the range of ca. 7-12.5 nm [6]. A large number of pores, channels, and cavities in MOFs provide the therapeutic agents with excellent carriers for the delivery of proteins, drugs, genes, Deoxyribonucleic acid (DNA), and ribonucleic acid (RNA) through covalent and non-covalent interactions [7,8]. Nevertheless, optimizing pore size for controlled release behavior depends on several parameters, mainly the interaction between drug and framework.

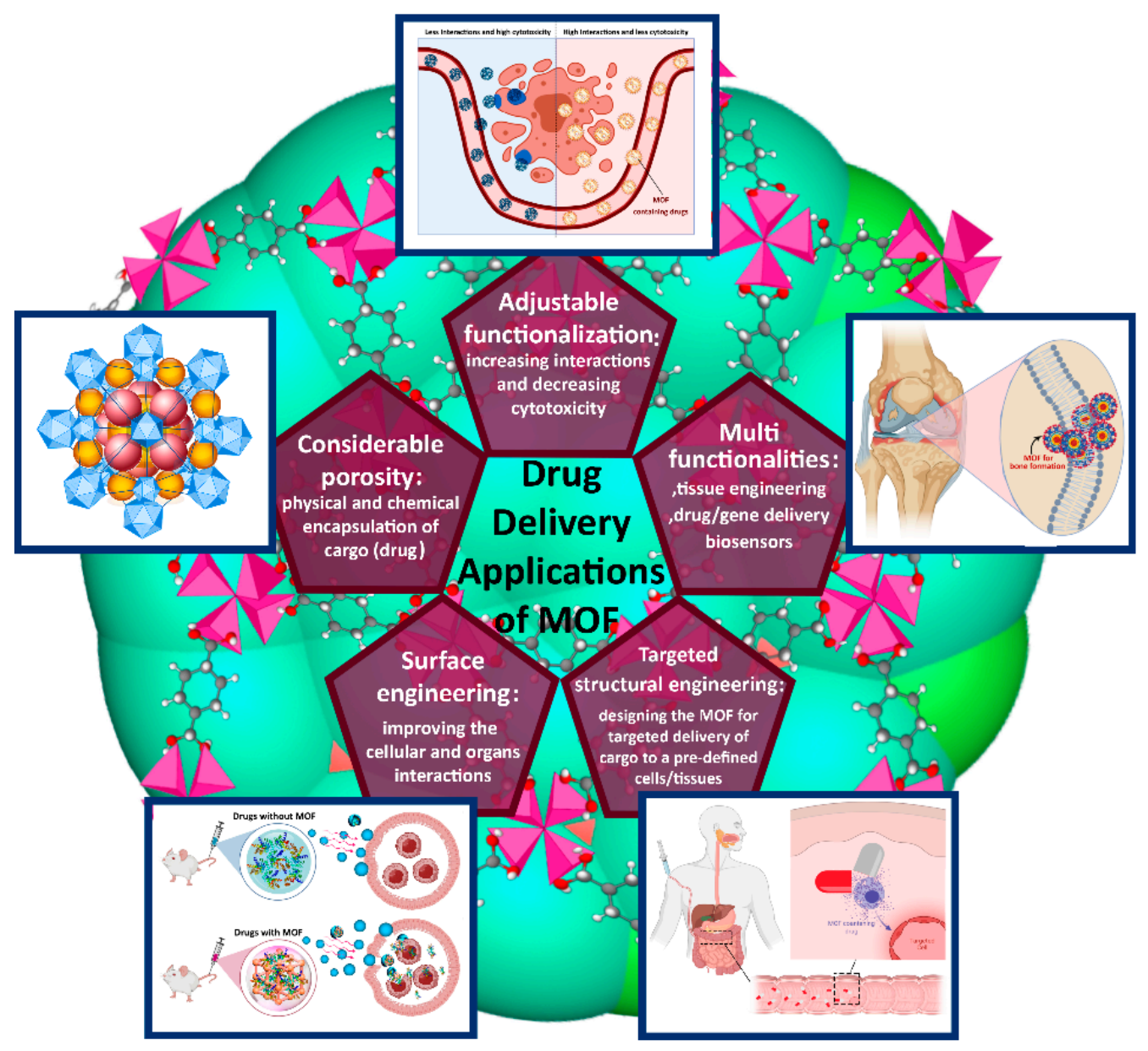

Scheme 1. A schematic illustration of the main applications of MOFs in drug delivery. 
Three kinds of cargo loadings or encapsulation strategies have systematically been applied for the encapsulation of therapeutic agents (such as chemically-synthesized small molecules, botanically available molecules, biotherapeutic macromolecules, and nucleic acids-based therapeutic agents) in MOFs; these are classical (direct assembly), modern (postsynthesis), and mixed strategies. The encapsulation strategy can be selected based on the state of the cargo-MOFs interactions. The direct assembly strategy has a one-pot nature in which the cargo participates in the MOF formation in situ through its coordinated functions that bond to the metal ligands. Facile synthesis of nanoparticles having various size and morphology (e.g., nanoparticles with approximately $40 \mathrm{~nm}$, nanorods of $80 \mathrm{~nm} \times 80 \mathrm{~nm} \times$ $1000 \mathrm{~nm}$, and nanoplates around 100-200 nm), proper distribution, and high loading of cargos (such as pamidronate (Pam), zoledronate (Zol), doxorubicin hydrochloride (DOX), c,c,t-(diamminedichlorodisuccinato) Pt (IV) (DSCP), PTT, PDT) to the NMOFs ( $\approx 60-75$ wt. $\%)$ are the main advantageous features of this therapeutic strategy. However, the delivery performance of this strategy is governed by the kinetics of cargo decomposition in the biological environment. MOFs, including Materials of Institute Lavoisier (MIL)-100, Zeolite imidazolate framework (ZIF)-8, and University of Oslo (UiO)-66, are the most popular structures employed for direct assembly encapsulation. Unlike the direct assembly approach, the post-synthesis strategy is a two-step synthesis. First, the desired NMOF structure having a defined size, morphology, and characteristics is synthesized. Second, the cargo is encapsulated in NMOFs with the aid of coordinative metal sites, functional sites of the struts, or the defect in the ligands of the metal nodes. Recently, some molecules named "modulator" (e.g., monocarboxylic acid) have been used to facilitate the formation of the defect in the ligands that substantially enhances the ability of NMOFs to accept and release cargos. Although the resulting spherical NMOFs (having a diameter of ca. 70-180 nm) can host some cargos (diiodo-substituted BODIPYs (I2-BDP), oligohistidine-Tags (His-Tags) peptides or proteins, phosphate-modified DNA) in a more controlled manner compared to NMOFs prepared via direct assembly, the loading level of the latter strategy is relatively low (3-25 wt.\%) [9-11]. MOFs, including MIL and UiO, are most prevalently developed by post-synthesis encapsulation. It is now well understood that metastatic tumor and cancer progression unavoidably occur by the alteration of the metabolism, in addition to uncontrolled mutation and hypoxia-induced angiogenesis [12,13]. This situation demands an efficient delivery system that represents synergistic cargo encapsulation and release, e.g., the cargo should overcome the blood-brain barrier (BBB). The mixed strategy makes good use of both classical and modern approaches, such that nanorods (50-100 nm length and 20-30 nm width) with an intermediate loading capacity (40-60 wt.\%) are formed. The NMOF structure developed by this method can encapsulate inhibitors, indoleamine 2,3-dioxygenase (IDOi), (5,10,15,20-tetra(p-benzoato) chlorine $\left(\mathrm{H}_{4} \mathrm{TBC}\right)$, olsalazine, and phenethylamine. MOFs, including TBC-Hf and $\mathrm{Mg}_{2}(\mathrm{olz})$, are the most popular structures used in mixed encapsulation. Examples also exist of multivariate modulation strategies, which permit the loading of two or three kinds of drugs in MOFs, e.g., Zr MOF UiO-66 [14].

\section{Stimuli-Responsive MOFs for Cargo Delivery}

Stimuli-responsible MOFs are a class of nanomaterials that can be treated in singlestimuli-responsive and multi-stimuli-responsive nanocarriers. They can not only encapsulate cargos at the desired level depending on the synthesis and encapsulation strategy, but also respond monotonically to the stimuli, such as temperature, $\mathrm{pH}$, ion, magnetic field, and pressure. The $\mathrm{pH}$-responsive frameworks are the most common among single-stimuliresponsive MOFs for cancer therapy, bearing in mind the sensitivity of MOFs to the $\mathrm{pH}$ and the acidity of the tumor microenvironment. Some examples of $\mathrm{pH}$-responsive structures are poly(acrylic acid)@zeolitic imidazolate framework-8 (PAA@ZIF-8), DOX incorporated silica-supported 1,1'-(1,4-butanediyl) bis (imidazole) (bbi), and DOX/Fe(bbi)@SiO ${ }_{2}-\mathrm{FA}$, $\mathrm{UiO}-66$, and, more recently, gadolinium (III)-based MOFs. In some cases, the regulation of $\mathrm{pH}$ may allow for $100 \%$ release of cargos, an advanced feature of $\mathrm{pH}$-sensitive MOFs. ZIF-8, UiO-66, porous coordination network (PCN)-221, and Zhejiang University (ZJU)-101 are 
examples of $\mathrm{pH}$-responsive MOFs. Magnetically responsive MOFs are designed to deliver cargos under magnetic fields, e.g., magnetic hyperthermia and magnetic resonance imaging (MRI) [15-17]. A feature of this therapeutic approach is the ability to apply multi-stage delivery of drugs over a predesigned release period. $\mathrm{Fe}_{3} \mathrm{O}_{4}-\mathrm{Cu}_{3}(\mathrm{BTC})_{2}$, and $\Upsilon-\mathrm{Fe}_{2} \mathrm{O}_{3}-\mathrm{MIL}-53$ (Al) are examples of MOFs with a magnetic-responsive characteristic. Ion-responsive MOFs are engineered nanostructures grounded on a physicochemical concept. In such structures, the penetration of the cargo from MOFs to the biological environment is fueled by the electrostatic interactions between the MOF and the cargo. BioMOF-1 and MOF-74-Fe (III) are examples of MOFs possessing an ion-responsive characteristic. Temperature-responsive MOFs are sensitive to heat and appear to be promising nanocarriers for cancer therapy. The release of cargo takes place at a specified temperature, and targeted delivery from MOFs is attained by temperature regulation. UiO-66-Poly(N-isopropylacrylamide) (PNIPAM), ZJU-63- $\mathrm{CH}_{3}$, and generally temperature-sensitive polymer-coated MOFs are examples of temperature-responsive MOFs. Engineered MOFs should avoid accelerated delivery of the drug before being exposed to the target tissue $[18,19]$. This can be achieved by pressure-responsive MOFs; for instance, ZJU-800 is studied as a pressure-sensitive MOF. The multiplicity of parameters contributing to the success or failure of a DDS is the main reason behind developing innovative multiple-stimuli-responsive MOF structures. FeBTC@Zn-BTC, CP5-capped UMCM-1-NH-Py, CP5-capped UiO-66-NH 2 , PEG-RGD- $\beta$ CDSS-MIL-101, and $\beta C D$-capped UiO-68-azo are examples of multiple-stimuli-responsive MOFs. Such systems are still immature and should be optimized for a targeted delivery mission $[20,21]$.

\section{Functionalization of MOFs for Cargo Delivery}

Because MOFs are highly porous and have a very high surface/volume ratio with extremely ordered structures, their cavities and lateral surfaces can more potently react with functional groups [22,23]. This can be carried out in situ or through functionalization of the pre-MOF structure. The functionalization of MOFs provides the therapeutic agents with a higher loading capacity. Typically, surface adsorption, pore encapsulation, covalent binding, and the use of the functional molecules as the building blocks are the possible approaches for the functionalization of MOFs. Functional molecules can be easily adsorbed on the MOF surface, given their highly porous structure [24,25]. This phenomenon is supported by the hydrogen bonding, van der Waals interactions, and $\pi-\pi$ interactions, as applied in enzyme immobilization. UiO-66-NH $\mathrm{NH}_{2}$, ZIF-8, and Ni-IRMOF-74-II MOFs are developed for the surface adsorption process. Pore encapsulation is also used to functionalize MOF, as an in situ process in which larger molecules (functional molecules) are trapped in a highly porous structure of the MOF, and functionalization occurs based on immobilization. MP-11@Tb-mesoMOF and different bioconjugate forms of PCN-333 MOFs are obtained through pore encapsulation [26-28]. Covalent bonding is the third method implemented in MOF functionalization, and MIL-88B (Cr), MIL-101 (Cr), and Zr-based MOFs are a few examples of functionalized MOFs synthesized by this method. Organic linkers and inorganic metal clusters can form covalent bonds in the MOF structure. The click reaction is an example of this method. The functional molecules are the building blocks of MOFs for the synthesis of bio-based MOFs, in which amino acids, peptides nucleobases, and saccharides are examined as organic ligands. $\mathrm{Zn}_{8}(\mathrm{ad})_{4}(\mathrm{BPDC})_{6} \mathrm{O} \cdot 2 \mathrm{Me}_{2} \mathrm{NH}_{2} \cdot 8 \mathrm{DMF} \cdot 11 \mathrm{H}_{2} \mathrm{O}$ (bioMOF-1), and $\left(\mathrm{Zn}_{8}(\mathrm{ad})_{4}(\mathrm{BPDC})_{6} \mathrm{O}_{2} \cdot 4 \mathrm{Me}_{2} \mathrm{NH}_{2} \cdot 49 \mathrm{DMF} \cdot 31 \mathrm{H}_{2} \mathrm{O}\right)$ (bioMOF-100) MOFs are obtained through this process $[4,29]$.

\section{Applications of MOFs in Drug Delivery}

Thus far, several nanomaterials have been applied in DDS, mainly carbon-based nanostructures including reduced graphene oxide (rGO), multi-walled carbon nanotube (MWCNT), and different types of natural and synthetic polymers. Despite their relative cell viability and low immune response inside the microorganisms, they have poor stability, lack the ability of modifications, and have confined porous structures. Inorganic-based 
nanomaterials, especially MOFs, emerged as a new material for DDS with improved properties compared to the conventional DDS. MOFs are not only promising due to their physicochemical structures and morphology, but also due to their ability to provide a wide range of interactions on the surface or inside the porosities and interconnected channels. For instance, MOFs can provide full physical interaction with the cargo by synthesizing free-functional groups such as $\mathrm{UiO}-66$; or considerable $\pi-\pi$ interactions between the host (MOFs) and the guest (cargos) in the synthesis of $\pi$-rich MOFs.

Moreover, MOFs are highly stable and well-organized 3D nanostructures with the potential for facile pore engineering by manipulating synthesis routes. Increasing the temperature by $10-50 \%$ results in an increase in the pore size and pore volume at the rate of $7-62 \%$. Further, other parameters, including $\mathrm{pH}$, the speed of the stirrer, solvent(s), and the purity of precursors, could change the pore size, pore volume, surface area, and even the size and zeta potential. Therefore, normal and even stimuli-responsive MOFs could be used in targeted DDS, suitable for different cell lines, organs, and targeted tissues by changing synthesis parameters. From another perspective, modifying the surface and inside of the porosities of MOFs could provide a wide range of interactions with the cargos, ranging from drugs to sensitizers and genetic materials (Table 1). By changing the surface functionality from hydroxides to amine(s), amide(s), and imide(s), the payload efficiency of the selected drug increases by an average rate of $38 \%$. Moreover, natural polymers and leaf extracts on the surface of $\mathrm{Cr}, \mathrm{Zr}$, and $\mathrm{Zn}$ MOFs can enhance the relative cell viability by the rate of $2-14 \%$, improve stability up to $150 \mathrm{~h}$, and provide considerable $\mathrm{pH}$ tolerance $(3.5<\mathrm{pH}<9)[30-32]$.

Table 1. A literature survey of the MOF-based nanomaterials for cargo delivery.

\begin{tabular}{|c|c|c|c|c|c|c|}
\hline $\begin{array}{l}\text { MOF-Based } \\
\text { Nanomaterial }\end{array}$ & Cargo & Function & $\begin{array}{c}\text { Essential } \\
\text { Components }\end{array}$ & $\begin{array}{l}\text { Targeted Cell } \\
\text { Line(s) }\end{array}$ & Disadvantages & Refs. \\
\hline $\begin{array}{c}\text { MIL-101- } \\
\mathrm{NH}_{2} @ \text { silica } \\
\text { shell@RGDfk }\end{array}$ & Cisplatin & $\begin{array}{l}\text { Chemotherapy, } \\
\text { Optical imaging, } \\
\text { Targeted drug } \\
\text { delivery, }\end{array}$ & $\begin{array}{c}\text { 1,4-BDC-NH2, } \\
\text { Fe }^{3+} \\
\text { Br-BODIPY, } \\
\text { silica shell }\end{array}$ & HT-29 & $\begin{array}{l}\text { toxicity in higher } \\
\text { concentrations, } \\
\text { Not green, } \\
\text { complex } \\
\text { synthesis method }\end{array}$ & [33] \\
\hline $\mathrm{Zn}-\mathrm{H}_{2} \mathrm{BDP}$ & Mitoxantrone & $\begin{array}{l}\text { Sustained drug } \\
\text { release in more } \\
\text { sophisticated } \\
\text { conditions, } \\
\text { Chemotherapy, and } \\
\text { reducing toxicity }\end{array}$ & $\mathrm{Zn}^{2+}, \mathrm{H}_{2} \mathrm{BDP}$ & J774 & $\begin{array}{l}\text { Not applicable } \\
\text { for in vivo } \\
\text { experiments, not } \\
\text { green }\end{array}$ & [34] \\
\hline $\begin{array}{c}\text { Mn- } \\
\text { bisphosphonate@peg- } \\
\text { AA }\end{array}$ & Zoledronate & $\begin{array}{l}\text { Magnetic resonance } \\
\text { imaging (MRI) } \\
\text { contrast agent, } \\
\text { chemotherapy }\end{array}$ & $\begin{array}{l}\text { DOPA, DSPE, } \\
\text { DOPC, } \\
\text { anisamide, } \\
\mathrm{Mn}^{2+}\end{array}$ & AsPC-1, MCF-7 & $\begin{array}{l}\text { Expensive, Not } \\
\text { green, toxic in } \\
\text { some higher } \\
\text { concentrations }\end{array}$ & [35] \\
\hline Zn-TATAT & $5-\mathrm{Fu}$ & $\begin{array}{l}\text { Sustained drug } \\
\text { release in more } \\
\text { sophisticated } \\
\text { conditions, } \\
\text { Chemotherapy, and } \\
\text { reducing toxicity }\end{array}$ & TaTAT, $\mathrm{Zn}^{2+}$ & - & $\begin{array}{l}\text { Considerable } \\
\text { aggregations in } \\
\text { most of the } \\
\text { concentrations, } \\
\text { limited usage for } \\
\text { in vivo } \\
\text { experiments }\end{array}$ & [36] \\
\hline $\begin{array}{l}\text { UiO-67@ and } \\
\text { UiO-66@PCL }\end{array}$ & Taxol, Cisplatin & $\begin{array}{l}\text { Sustained release of } \\
\text { drug in a limited } \\
\text { condition, } \\
\text { Chemotherapy, and } \\
\text { reduced toxicity }\end{array}$ & $\begin{array}{c}\text { UiO-67, UiO-66, } \\
\text { Polycaprolac- } \\
\text { tone, } \\
\text { Polyethylene } \\
\text { glycol }\end{array}$ & $\begin{array}{l}\text { HSC-3, } \\
\text { U-87MG }\end{array}$ & $\begin{array}{l}\text { high-temperature } \\
\text { of synthesis, not } \\
\text { green, drastic } \\
\text { toxicity in some } \\
\text { concentrations, } \\
\text { not cost-effective }\end{array}$ & [37] \\
\hline
\end{tabular}


Table 1. Cont.

\begin{tabular}{|c|c|c|c|c|c|c|}
\hline $\begin{array}{c}\text { MOF-Based } \\
\text { Nanomaterial }\end{array}$ & Cargo & Function & $\begin{array}{c}\text { Essential } \\
\text { Components }\end{array}$ & $\begin{array}{l}\text { Targeted Cell } \\
\text { Line(s) }\end{array}$ & Disadvantages & Refs. \\
\hline $\mathrm{UiO}-66 @ \mathrm{Fe}_{3} \mathrm{O}_{4}$ & DOX & $\begin{array}{l}\text { Reduced toxicity, } \\
\text { Chemotherapy }\end{array}$ & $\begin{array}{c}\text { 1,4-BDC, } \mathrm{ZrCl}_{4} \\
\mathrm{Fe}_{3} \mathrm{O}_{4}\end{array}$ & 3T3, HeLa & $\begin{array}{l}\text { Not green, } \\
\text { limited } \\
\text { utilization, } \\
\text { non-sustained } \\
\text { release }\end{array}$ & [38] \\
\hline MIL-100-Нер & Caffeine & $\begin{array}{l}\text { Chemotherapy, } \\
\text { limited inflammation } \\
\text { response }\end{array}$ & $\begin{array}{c}\text { 1,3,5-BTC, } \mathrm{Fe}^{3+} \\
\text { Rhodamine, } \\
\text { Heparin }\end{array}$ & HL60, J774.A1 & $\begin{array}{l}\text { Not green, not } \\
\text { sequential drug } \\
\text { release, limited } \\
\text { usage, difficult } \\
\text { synthesis method }\end{array}$ & [39] \\
\hline ZIF-90@Fe ${ }_{3} \mathrm{O}_{4}$ & $5-\mathrm{Fu}$ & $\begin{array}{l}\text { Chemotherapy, MRI, } \\
\text { Magnetic thermal } \\
\text { delivery }\end{array}$ & $\begin{array}{c}\text { Rat serum } \\
\text { albumin, } \mathrm{Zn}^{2+} \\
\mathrm{Fe}_{3} \mathrm{O}_{4} \\
\text { Polyvinylpyrroli- } \\
\text { done } \\
\text { (PVP) }\end{array}$ & - & $\begin{array}{l}\text { Not green, } \\
\text { considerable } \\
\text { cytotoxicity, } \\
\text { limited } \\
\text { application }\end{array}$ & [40] \\
\hline $\begin{array}{c}\text { ZIF-8- } \\
\mathrm{Au}_{25} @ \mathrm{Fe}_{3} \mathrm{O}_{4}\end{array}$ & - & $\begin{array}{l}\text { Targeted delivery, } \\
\text { MRI, chemotherapy, } \\
\text { photodynamic } \\
\text { therapy }\end{array}$ & $\begin{array}{l}\mathrm{Fe}_{3} \mathrm{O}_{4}, \mathrm{Zn}^{2+} \\
\mathrm{HMelM}\end{array}$ & HeLa L929 & $\begin{array}{c}\text { Not green, } \\
\text { considerable } \\
\text { toxicity, harsh } \\
\text { synthesis } \\
\text { condition, limited } \\
\text { sustained release }\end{array}$ & [41] \\
\hline $\begin{array}{l}\text { IRMOF-3@FA- } \\
\text { RITC@Fe }{ }_{3} \mathrm{O}_{4}\end{array}$ & Paclitaxel & $\begin{array}{l}\text { Optical imaging, } \\
\text { MRI, Chemotherapy }\end{array}$ & $\begin{array}{c}\text { Folic acid, } \mathrm{PVP}, \\
\mathrm{Fe}_{3} \mathrm{O}_{4}, \mathrm{Zn}^{2+} \\
\text { rhodamine B } \\
\text { isothiocyanate }\end{array}$ & NIH3T3, HeLa & $\begin{array}{c}\text { Not green, } \\
\text { difficult synthesis } \\
\text { method, very low } \\
\text { yield of synthesis, } \\
\text { toxic }\end{array}$ & [42] \\
\hline $\begin{array}{c}\text { MIL- } \\
100 @ \mathrm{C} @ \mathrm{Fe}_{3} \mathrm{O}_{4}\end{array}$ & $\begin{array}{l}\text { Dihydroxyacetone } \\
\text { (DHA), Fe(III) }\end{array}$ & $\begin{array}{c}\text { MRI, pH-responsive } \\
\text { delivery, optical } \\
\text { imaging }\end{array}$ & $\begin{array}{c}\mathrm{Fe}_{3} \mathrm{O}_{4}, \mathrm{Fe}^{3+} \\
\text { ferrocene, } \\
1,3,5-\mathrm{BTC}\end{array}$ & HeLa, A549 & $\begin{array}{l}\text { Not green, low } \\
\text { yield of synthesis, } \\
\text { harsh synthesis } \\
\text { method }\end{array}$ & [43] \\
\hline $\begin{array}{l}\text { Mn coordination } \\
\text { polymers }\end{array}$ & $\begin{array}{l}\text { Non-steroidal } \\
\text { anti- } \\
\text { inflammatory } \\
\text { drugs } \\
\text { (NSAIDs) }\end{array}$ & $\begin{array}{l}\text { Drug delivery, cell } \\
\text { imaging }\end{array}$ & $\begin{array}{l}\text { NSAIDs, } \\
\mathrm{Mn}\left(\mathrm{ClO}_{4}\right)_{2}\end{array}$ & RAW264.7 & $\begin{array}{l}\text { Not green, } \\
\text { complicated } \\
\text { synthesis } \\
\text { procedure, not } \\
\text { scalable, limited } \\
\text { toxicity }\end{array}$ & [44] \\
\hline UiO-PDT & - & $\begin{array}{l}\text { Photodynamic } \\
\text { therapy }\end{array}$ & $\begin{array}{c}\text { 12-BDP, } \\
1,4-\mathrm{BDC}, \mathrm{ZrCl}_{4}\end{array}$ & $\begin{array}{l}\text { CT26, C26, } \\
\text { B16F10 }\end{array}$ & $\begin{array}{c}\text { Not green, } \\
\text { limited toxicity, } \\
\text { expensive } \\
\text { synthesis method }\end{array}$ & [45] \\
\hline TCPP-Hf-PEG & - & $\begin{array}{l}\text { Radiation therapy, } \\
\text { photodynamic } \\
\text { therapy }\end{array}$ & $\begin{array}{c}\text { Meso-Tetra(4- } \\
\text { carboxyphenyl) } \\
\text { porphine } \\
\text { (TCPP), HfCl } \\
\text { polyethyleneg- } \\
\text { lycol } \\
\text { (PEG) }\end{array}$ & $\begin{array}{c}\text { NIH3T3, HeLa, } \\
4 \mathrm{~T} 1\end{array}$ & $\begin{array}{c}\text { Not green, } \\
\text { limited cell } \\
\text { viability, limited } \\
\text { in vivo } \\
\text { applications }\end{array}$ & [46] \\
\hline
\end{tabular}


Table 1. Cont.

\begin{tabular}{|c|c|c|c|c|c|c|}
\hline $\begin{array}{l}\text { MOF-Based } \\
\text { Nanomaterial }\end{array}$ & Cargo & Function & $\begin{array}{c}\text { Essential } \\
\text { Components }\end{array}$ & $\begin{array}{l}\text { Targeted Cell } \\
\text { Line(s) }\end{array}$ & Disadvantages & Refs. \\
\hline MIL-10@PB & Artemisinin & $\begin{array}{l}\text { Optical imaging, } \\
\text { MRI, Chemotherapy }\end{array}$ & $\begin{array}{c}\text { PVP, } 1,3,5-\mathrm{BTC}, \\
\mathrm{Fe}^{3+}\end{array}$ & HeLa & $\begin{array}{l}\text { Not green, } \\
\text { complex } \\
\text { synthesis } \\
\text { procedure, } \\
\text { relatively low cell } \\
\text { viability }\end{array}$ & [47] \\
\hline $\begin{array}{l}\text { p(HEMA)-GMA- } \\
\text { UiO-66 }\end{array}$ & $\begin{array}{l}\text { DOX and } \\
\text { pCRISPR }\end{array}$ & $\begin{array}{c}\text { Targeted drug/gene } \\
\text { delivery, } \\
\text { sustained-release in } \\
\text { tissue and cells, } \\
\text { stimuli-responsive } \\
\text { delivery, lowest } \\
\text { cytotoxicity, fully } \\
\text { biocompatible }\end{array}$ & $\begin{array}{c}\text { UiO-66, } \\
\text { Glycidyl } \\
\text { methacrylate } \\
\text { (GMA), } \\
\text { (Hydroxyethyl) } \\
\text { methacrylate } \\
\text { (HEMA) }\end{array}$ & $\begin{array}{l}\text { HepG2, HeLa, } \\
\text { HEK-293, PC12 }\end{array}$ & $\begin{array}{l}\text { Limited in vivo } \\
\text { applications }\end{array}$ & [48] \\
\hline 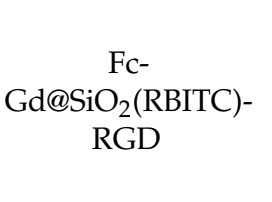 & - & Targeting, MRI & $\begin{array}{c}\mathrm{Fc}, \mathrm{Gd}^{3+}, \\
\text { RBITC, silica }\end{array}$ & MCF-7, U87MG & $\begin{array}{l}\text { Not green, } \\
\text { limited in vivo } \\
\text { usage, } \\
\text { considerable } \\
\text { cytotoxicity }\end{array}$ & [49] \\
\hline $\begin{array}{l}\text { p(NIPAM)-GMA- } \\
\text { UiO-66 }\end{array}$ & $\begin{array}{l}\text { DOX and } \\
\text { pCRISPR }\end{array}$ & $\begin{array}{c}\text { Targeted drug/gene } \\
\text { delivery, sustained } \\
\text { release in tissue and } \\
\text { cells, } \\
\text { stimuli-responsive } \\
\text { delivery, lowest } \\
\text { cytotoxicity, fully } \\
\text { biocompatible }\end{array}$ & $\begin{array}{l}\text { UiO-66, GMA, } \\
\text { NIPAM }\end{array}$ & $\begin{array}{l}\text { HEK-293, HeLa, } \\
\text { HepG2, PC12 }\end{array}$ & $\begin{array}{l}\text { Limited in vivo } \\
\text { applications }\end{array}$ & [48] \\
\hline
\end{tabular}

\section{Conclusions, Challenging Features, and Future Perspectives}

MOFs are progressively developing from generation to generation to meet the requirements for biomedical applications. MOFs are excellent nanocarriers, but their size, shape, functionality, and loading capacity should be further controlled or optimized for a particular application. In recent years, the green synthesis of MOFs for biomedical applications has been the center of attention. This is because green MOFs are inherently sustainable with acceptable biocompatibility. Nevertheless, they have a limited level of stability in aqueous media and deteriorate at high temperatures. Therefore, their potential as cargo for encapsulation and DDS should be further enhanced. Currently, there is global concern regarding the situation caused by the SARS-CoV-2 virus or COVID-19 pandemic. Several companies commercialized their products to vaccinate people against SARS-CoV2/COVID-19 [50]. Nevertheless, millions of people globally are struggling to survive, mainly because of the inability to access vaccines, the regional mutations of COVID-19, and/or the ineffectiveness of the vaccine. Thus, vaccines still need to be optimized to enhance their protection window and lessen their side-effects for long-term immunity to COVID-19 infection. Even in the range of ppm, some side effects, such as thrombosis, raise serious concerns about COVID-19 vaccines. The rapid production of mRNA vaccines during the COVID-19 pandemic encoded for the protein of SARS-CoV-2 can be responded to via the design of multi-responsive nanoparticles. Bio-MOFs are a promising class of MOFs, which can be prepared using biological endogenous organic ligands, e.g., amino acids, peptides, proteins, porphyrins, and saccharides. It is speculated that mRNA can be more stable and resistant to RNase-mediated degradation if it is complexed with positively charged bio-MOFs, which can further form self-assembled virus-sized particles suitable for administration through different routes. During the endocytose process, the Bio-MOFs 
can facilitate endosomal escape and deliver the genetic cargo in the cytosol, where the mRNA is translated into antigenic proteins, forcing the immune system machinery to produce the targeted antibodies. A current drawback of nanoparticulate delivery of vaccine formulations is their long-term storage limitations, which create logistical challenges to their prospective distribution and administration. Bio-MOFs might be of great interest to those working on the concept of vaccine delivery through nanomedicine strategies due to their biocompatibility, nano-size structure, and physicochemical characteristics, which can protect the vaccine cargos from degradation, and suggest controlled biodistribution and intracellular localization and release of the vaccine. We believe that MOFs can contribute to enlightening the future perspective for developing highly sophisticated and critical tasks in the field of drug delivery. The current state of the literature indicates that green MOFs have neither been comprehensively reviewed nor systematically classified. Moreover, the selection of green multivalent ligands and struts together with transition metals remain challenging aspects of MOF synthesis for drug delivery applications.

Author Contributions: All authors made a significant contribution to the work reported, whether that is in the conception, study design, execution, acquisition of data, or in all these areas; took part in drafting, revising or critically reviewing the article; gave final approval of the version to be published; have agreed on the journal to which the article has been submitted; and agree to be accountable for all aspects of the work. All authors have read and agreed to the published version of the manuscript.

Funding: Ebrahim Mostafavi would like to acknowledge support from the National Institute of Biomedical Imaging and Bioengineering (5T32EB009035).

Institutional Review Board Statement: Not applicable.

Informed Consent Statement: Not applicable.

Conflicts of Interest: The authors declare no conflict of interest.

\section{References}

1. Yap, M.H.; Fow, K.L.; Chen, G.Z. Synthesis and applications of MOF-derived porous nanostructures. Green Energy Environ. 2017, 2, 218-245. [CrossRef]

2. Maity, A.; Polshettiwar, V. Scalable and sustainable synthesis of size-controlled monodisperse dendritic fibrous nanosilica quantified by E-factor. ACS Appl. Nano Mater. 2018, 1, 3636-3643. [CrossRef]

3. Quercia, G.; Lazaro, A.; Geus, J.; Brouwers, H. Characterization of morphology and texture of several amorphous nano-silica particles used in concrete. Cem. Concr. Compos. 2013, 44, 77-92. [CrossRef]

4. Sun, Y.; Zheng, L.; Yang, Y.; Qian, X.; Fu, T.; Li, X.; Yang, Z.; Yan, H.; Cui, C.; Tan, W. Metal-organic framework nanocarriers for drug delivery in biomedical applications. Nano-Micro Lett. 2020, 12, 1-29. [CrossRef]

5. Stock, N.; Biswas, S. Synthesis of metal-organic frameworks (MOFs): Routes to various MOF topologies, morphologies, and composites. Chem. Rev. 2012, 112, 933-969. [CrossRef]

6. Haydar, M.A.; Abid, H.R.; Sunderland, B.; Wang, S. Metal organic frameworks as a drug delivery system for flurbiprofen. Drug Des. Dev. Ther. 2017, 11, 2685. [CrossRef]

7. Li, R.; Chen, T.; Pan, X. Metal-Organic-Framework-Based Materials for Antimicrobial Applications. ACS Nano 2021, 15, 3808-3848. [CrossRef]

8. Duman, F.D.; Forgan, R.S. Applications of nanoscale metal-organic frameworks as imaging agents in biology and medicine. J. Mater. Chem. B 2021. [CrossRef]

9. Wang, L.; Zheng, M.; Xie, Z. Nanoscale metal-organic frameworks for drug delivery: A conventional platform with new promise. J. Mater. Chem. B 2018, 6, 707-717. [CrossRef]

10. Rabiee, N.; Bagherzadeh, M.; Jouyandeh, M.; Zarrintaj, P.; Saeb, M.R.; Mozafari, M.; Shokouhimehr, M.; Varma, R.S. Natural Polymers Decorated MOF-MXene Nanocarriers for Co-delivery of Doxorubicin/pCRISPR. ACS Appl. Bio Mater. 2021, 4, 5106-5121. [CrossRef]

11. Sun, X.; He, G.; Xiong, C.; Wang, C.; Lian, X.; Hu, L.; Li, Z.; Dalgarno, S.J.; Yang, Y.-W.; Tian, J. One-Pot Fabrication of Hollow Porphyrinic MOF Nanoparticles with Ultrahigh Drug Loading toward Controlled Delivery and Synergistic Cancer Therapy. ACS Appl. Mater. Interfaces 2021, 13, 3679-3693. [CrossRef] [PubMed]

12. Petrova, V.; Annicchiarico-Petruzzelli, M.; Melino, G.; Amelio, I. The hypoxic tumour microenvironment. Oncogenesis 2018, 7, 1-13. [CrossRef] [PubMed]

13. Lawson, S.; Newport, K.; Pederniera, N.; Rownaghi, A.A.; Rezaei, F. Curcumin Delivery on Metal-Organic Frameworks: The Effect of the Metal Center on Pharmacokinetics within the M-MOF-74 Family. ACS Appl. Bio Mater. 2021, 4, 3423-3432. [CrossRef] 
14. Abánades Lázaro, I.; Wells, C.J.; Forgan, R.S. Multivariate Modulation of the Zr MOF UiO-66 for Defect-Controlled Combination Anticancer Drug Delivery. Angew. Chem. Int. Ed. 2020, 59, 5211-5217. [CrossRef]

15. Cui, R.; Zhao, P.; Yan, Y.; Bao, G.; Damirin, A.; Liu, Z. Outstanding Drug-Loading/Release Capacity of Hollow Fe-Metal-Organic Framework-Based Microcapsules: A Potential Multifunctional Drug-Delivery Platform. Inorg. Chem. 2021, 60, $1664-1671$. [CrossRef]

16. Wen, T.; Quan, G.; Niu, B.; Zhou, Y.; Zhao, Y.; Lu, C.; Pan, X.; Wu, C. Versatile Nanoscale Metal-Organic Frameworks (nMOFs): An Emerging 3D Nanoplatform for Drug Delivery and Therapeutic Applications. Small 2021, 17, 2005064. [CrossRef]

17. Luo, Z.; Fan, S.; Gu, C.; Liu, W.; Chen, J.; Li, B.; Liu, J. Metal-organic framework (MOF)-based nanomaterials for biomedical applications. Curr. Med. Chem. 2019, 26, 3341-3369. [CrossRef]

18. Nagata, S.; Kokado, K.; Sada, K. Metal-organic framework tethering PNIPAM for ON-OFF controlled release in solution. Chem. Commun. 2015, 51, 8614-8617. [CrossRef]

19. Karmakar, A.; Mileo, P.G.; Bok, I.; Peh, S.B.; Zhang, J.; Yuan, H.; Maurin, G.; Zhao, D. Thermo-Responsive MOF/Polymer Composites for Temperature-Mediated Water Capture and Release. Angew. Chem. Int. Ed. 2020, 59, 11003-11009. [CrossRef]

20. Wu, M.X.; Yang, Y.W. Metal-organic framework (MOF)-based drug/cargo delivery and cancer therapy. Adv. Mater. 2017, 29, 1606134. [CrossRef]

21. Hu, J.; Chen, Y.; Zhang, H.; Chen, Z.; Ling, Y.; Yang, Y.; Liu, X.; Jia, Y.; Zhou, Y. TEA-assistant synthesis of MOF-74 nanorods for drug delivery and in-vitro magnetic resonance imaging. Microporous Mesoporous Mater. 2021, 315, 110900. [CrossRef]

22. Allegretto, J.A.; Giussi, J.M.; Moya, S.E.; Azzaroni, O.; Rafti, M. Synthesis and characterization of thermoresponsive ZIF-8@ PNIPAm-co-MAA microgel composites with enhanced performance as an adsorption/release platform. RSC Adv. 2020, 10, 2453-2461. [CrossRef]

23. Jia, Y.; Su, H.; Wong, Y.-L.E.; Chen, X.; Chan, T.-W.D. Thermo-responsive polymer tethered metal-organic framework core-shell magnetic microspheres for magnetic solid-phase extraction of alkylphenols from environmental water samples. J. Chromatogr. A 2016, 1456, 42-48. [CrossRef]

24. Bieniek, A.; Terzyk, A.P.; Wiśniewski, M.; Roszek, K.; Kowalczyk, P.; Sarkisov, L.; Keskin, S.; Kaneko, K. MOF materials as therapeutic agents, drug carriers, imaging agents and biosensors in cancer biomedicine: Recent advances and perspectives. Prog. Mater. Sci. 2020, 117, 100743. [CrossRef]

25. Velásquez-Hernández, M.d.J.; Linares-Moreau, M.; Astria, E.; Carraro, F.; Alyami, M.Z.; Khashab, N.M.; Sumby, C.J.; Doonan, C.J.; Falcaro, P. Towards applications of bioentities@ MOFs in biomedicine. Coord. Chem. Rev. 2020, 429, 213651. [CrossRef]

26. de Koning, M.C.; van Grol, M.; Breijaert, T. Degradation of paraoxon and the chemical warfare agents VX, tabun, and soman by the metal-organic frameworks UiO-66-NH2, MOF-808, NU-1000, and PCN-777. Inorg. Chem. 2017, 56, 11804-11809. [CrossRef]

27. Ni, M.; Gong, M.; Li, X.; Gu, J.; Li, B.; Chen, Y. Dimensions of fluorescence kinetic concentration of doped morphology homologs synthesized by TCPP and UiO-66 MOF. Appl. Mater. Today 2021, 23, 100982. [CrossRef]

28. Chowdhuri, A.R.; Laha, D.; Chandra, S.; Karmakar, P.; Sahu, S.K. Synthesis of multifunctional upconversion NMOFs for targeted antitumor drug delivery and imaging in triple negative breast cancer cells. Chem. Eng. J. 2017, 319, 200-211. [CrossRef]

29. Bůžek, D.; Adamec, S.; Lang, K.; Demel, J. Metal-organic frameworks vs. buffers: Case study of UiO-66 stability. Inorg. Chem. Front. 2021, 8, 720-734. [CrossRef]

30. Zhang, L.; Liu, Z.; Deng, Q.; Sang, Y.; Dong, K.; Ren, J.; Qu, X. Nature-Inspired Construction of MOF@ COF Nanozyme with Active Sites in Tailored Microenvironment and Pseudopodia-Like Surface for Enhanced Bacterial Inhibition. Angew. Chem. Int. Ed. 2021, 60, 3469-3474. [CrossRef]

31. Zhang, Y.; Jang, Y.; Lee, J.-E.; Ahn, J.; Xu, L.; Holden, M.R.; Cornett, E.M.; Krajewski, K.; Klein, B.J.; Wang, S.-P. Selective binding of the PHD6 finger of MLL4 to histone H4K16ac links MLL4 and MOF. Nat. Commun. 2019, 10, 1-11. [CrossRef] [PubMed]

32. Zhao, Y.-W.; Wang, Y.; Zhang, X.-M. Homochiral MOF as circular dichroism sensor for enantioselective recognition on nature and chirality of unmodified amino acids. ACS Appl. Mater. Interfaces 2017, 9, 20991-20999. [CrossRef]

33. Taylor-Pashow, K.M.; Della Rocca, J.; Xie, Z.; Tran, S.; Lin, W. Postsynthetic modifications of iron-carboxylate nanoscale metalOrganic frameworks for imaging and drug delivery. J. Am. Chem. Soc. 2009, 131, 14261-14263. [CrossRef] [PubMed]

34. Rojas, S.; Carmona, F.J.; Maldonado, C.R.; Horcajada, P.; Hidalgo, T.; Serre, C.; Navarro, J.A.; Barea, E. Nanoscaled zinc pyrazolate metal-organic frameworks as drug-delivery systems. Inorg. Chem. 2016, 55, 2650-2663. [CrossRef] [PubMed]

35. Liu, D.; He, C.; Poon, C.; Lin, W. Theranostic nanoscale coordination polymers for magnetic resonance imaging and bisphosphonate delivery. J. Mater. Chem. B 2014, 2, 8249-8255. [CrossRef] [PubMed]

36. Sun, C.Y.; Qin, C.; Wang, C.G.; Su, Z.M.; Wang, S.; Wang, X.L.; Yang, G.S.; Shao, K.Z.; Lan, Y.Q.; Wang, E.B. Chiral nanoporous metal-organic frameworks with high porosity as materials for drug delivery. Adv. Mater. 2011, 23, 5629-5632. [CrossRef]

37. Filippousi, M.; Turner, S.; Leus, K.; Siafaka, P.I.; Tseligka, E.D.; Vandichel, M.; Nanaki, S.G.; Vizirianakis, I.S.; Bikiaris, D.N.; Van Der Voort, P. Biocompatible Zr-based nanoscale MOFs coated with modified poly ( $\varepsilon$-caprolactone) as anticancer drug carriers. Int J. Pharm. 2016, 509, 208-218. [CrossRef]

38. Zhao, H.-X.; Zou, Q.; Sun, S.-K.; Yu, C.; Zhang, X.; Li, R.-J.; Fu, Y.-Y. Theranostic metal-organic framework core-shell composites for magnetic resonance imaging and drug delivery. Chem. Sci. 2016, 7, 5294-5301. [CrossRef]

39. Bellido, E.; Hidalgo, T.; Lozano, M.V.; Guillevic, M.; Simón-Vázquez, R.; Santander-Ortega, M.J.; González-Fernández, Á.; Serre, C.; Alonso, M.J.; Horcajada, P. Heparin-engineered mesoporous iron metal-organic framework nanoparticles: Toward stealth drug nanocarriers. Adv. Healthc. Mater. 2015, 4, 1246-1257. [CrossRef] 
40. Fang, J.; Yang, Y.; Xiao, W.; Zheng, B.; Lv, Y.-B.; Liu, X.-L.; Ding, J. Extremely low frequency alternating magnetic field-triggered and MRI-traced drug delivery by optimized magnetic zeolitic imidazolate framework-90 nanoparticles. Nanoscale 2016, 8, 3259-3263. [CrossRef]

41. Yang, D.; Yang, G.; Gai, S.; He, F.; An, G.; Dai, Y.; Lv, R.; Yang, P. Au 25 cluster functionalized metal-organic nanostructures for magnetically targeted photodynamic/photothermal therapy triggered by single wavelength $808 \mathrm{~nm}$ near-infrared light. Nanoscale 2015, 7, 19568-19578. [CrossRef]

42. Chowdhuri, A.R.; Bhattacharya, D.; Sahu, S.K. Magnetic nanoscale metal organic frameworks for potential targeted anticancer drug delivery, imaging and as an MRI contrast agent. Dalton Trans. 2016, 45, 2963-2973. [CrossRef]

43. Wang, D.; Zhou, J.; Chen, R.; Shi, R.; Xia, G.; Zhou, S.; Liu, Z.; Zhang, N.; Wang, H.; Guo, Z. Magnetically guided delivery of DHA and Fe ions for enhanced cancer therapy based on pH-responsive degradation of DHA-loaded Fe $\mathrm{O}_{4} @ \mathrm{C} @ \mathrm{MIL}-100$ (Fe) nanoparticles. Biomaterials 2016, 107, 88-101. [CrossRef] [PubMed]

44. Paul, M.; Dastidar, P. Coordination Polymers Derived from Non-Steroidal Anti-Inflammatory Drugs for Cell Imaging and Drug Delivery. Chem. A Eur. J. 2016, 22, 988-998. [CrossRef] [PubMed]

45. Wang, W.; Wang, L.; Li, Z.; Xie, Z. BODIPY-containing nanoscale metal-organic frameworks for photodynamic therapy. Chem. Commun. 2016, 52, 5402-5405. [CrossRef] [PubMed]

46. Liu, J.; Yang, Y.; Zhu, W.; Yi, X.; Dong, Z.; Xu, X.; Chen, M.; Yang, K.; Lu, G.; Jiang, L. Nanoscale metal- organic frameworks for combined photodynamic \& radiation therapy in cancer treatment. Biomaterials 2016, 97, 1-9. [PubMed]

47. Wang, D.; Zhou, J.; Chen, R.; Shi, R.; Zhao, G.; Xia, G.; Li, R.; Liu, Z.; Tian, J.; Wang, H. Controllable synthesis of dualMOFs nanostructures for $\mathrm{pH}$-responsive artemisinin delivery, magnetic resonance and optical dual-model imaging-guided chemo/photothermal combinational cancer therapy. Biomaterials 2016, 100, 27-40. [CrossRef] [PubMed]

48. Rabiee, N.; Bagherzadeh, M.; Heidarian Haris, M.; Ghadiri, A.M.; Matloubi Moghaddam, F.; Fatahi, Y.; Dinarvand, R.; Jarahiyan, A.; Ahmadi, S.; Shokouhimehr, M. Polymer-Coated NH2-UiO-66 for the Codelivery of DOX/pCRISPR. ACS Appl. Mater. Interfaces 2021, 13, 10796-10811. [CrossRef] [PubMed]

49. Yang, H.; Qin, C.; Yu, C.; Lu, Y.; Zhang, H.; Xue, F.; Wu, D.; Zhou, Z.; Yang, S. RGD-Conjugated Nanoscale Coordination Polymers for Targeted T1- and T2- weighted Magnetic Resonance Imaging of Tumors in Vivo. Adv. Funct. Mater. 2014, 24, $1738-1747$. [CrossRef]

50. Verbeke, R.; Lentacker, I.; De Smedt, S.C.; Dewitte, H. The dawn of mRNA vaccines: The COVID-19 case. J. Control. Release 2021, 333, 511-520. [CrossRef] 